\title{
CYSTIC ECHINOCOCCOSIS IN SOUTHERN BRAZIL
}

\author{
Mario L. DE LA RUE
}

\begin{abstract}
SUMMARY
Cystic echinococcosis (CE) is very common in the southern part of Rio Grande do Sul State where sheep and cattle raising is the most important economical activity. Prevalence in intermediate hosts is well known due to reports in slaughterhouses while human reports are of discussed value. This is due to underreporting of cases and few epidemiological studies make it difficult to assess the situation of echinococcosis in the population. Whereas cattle infection rate is more or less stable around $12 \%$ of the slaughter animals, in sheep there has been an increasing number in the last five years. Some efforts have been done to control the zoonosis but no effective results were obtained so far. Probably educational efforts to change human practices (feeding dogs with raw viscera), periodic treatment of dogs with praziquantel and joined actions with slaughterhouses could bring more attention to improve some control measures.
\end{abstract}

KEYWORDS: Cystic echinococcosis; Epidemiology; Southern Brazil.

The southern Brazilian State (Rio Grande do Sul) is a region in which agriculture and livestock raising with related industries are the most important economical activities. Extensive cattle and sheep raising are predominant in farms associated sometimes with rice culture.

According to existent data, cystic echinococcosis (CE) is caused by the dog tapeworm Echinococcus granulosus (Batsch, 1786), which has long been recognized as an assembly of various distinct strains and, more recently, species ${ }^{17}$.

In farms, the habit of using dogs to help sheep raising activities coupled with the practice of feeding them with sheep's raw offal's perpetuates the parasite's life cycle. The agent of CE is widespread in an area of approximately 100,000 sq. Kilometers, which is close to the Uruguayan and Argentinean borders.

The first review of human cases was done by HARDEGGER ${ }^{11}$, from which two cases had previously been described in the Brazilian Medical literature, one in the city of São Paulo and the other in Rio de Janeiro. After that, BASSEWITZ ${ }^{2}$ carried out the first dog necropsy survey in the rural area of Santa Vitória do Palmar, next to the Uruguayan border, and identified that $17 \%$ were infected with the parasite. In 1918, BRUSQUE 5 performed a five years survey and observed that $56 \%$ of human cysts were located in the liver.

Domestic dogs (Canis familiaris) probably play the major role as a definitive host, but wild Canidae could have a secondary importance in environmental contamination. BASSEWITZ ${ }^{2}$ experimentally could infect the fox (Canis azural) inferring that it may act as a wild reservoir because it feeds itself with animal's carcasses in the field. Other Canidae that may be found in Rio Grande do Sul State, include Pseudalopex gymnocercus (Pampas-Fox), Cerdocyon thous (Crab-eating fox) and Chrysocyon brachyurous (Maned Wolf). Whether these animals have importance in the sylvatic cycle of Echinococcus has not yet been investigated.

The last E. granulosus survey was done by the Agricultural Secretary of the Rio Grande do Sul State in $1997^{6}$. At that time, from $14 \%$ to $50 \%$ of farm dogs were infected with the parasite and no more recent data is available.

As it is actually known, cystic echinococcosis affects predominantly farm dogs, or dogs living in rural areas, but a survey done by HOFFMANN et al. ${ }^{12}$ analyzing stray dogs captured in streets from a city in an endemic area, detected that five out of 65 dogs (7.7\%) presented the parasite in the feces and coproantigens were found in seven out of $65(10.1 \%)$. These facts indicate that attention has to be paid to urban contamination with the parasite's eggs and their risk to humans.

HAAG et al..$^{10}$ for the first time reported the presence of the cattle strain-G5 of E. granulosus in southern Brazil, and this finding was subsequently confirmed by DNA analysis but no information on geographic distribution and prevalence was provided ${ }^{1}$. Recently, some data were presented showing that the sheep strain is more prevalent than cattle strain ${ }^{7}$. In neighbouring Argentina, the presence of $E$. 
granulosus G1 (sheep strain), G2 (Tasmanian sheep strain), G6 (camel strain) and G7 (pig strain) was reported ${ }^{14}$.

Epidemiological data are very sparse and usually published in governamental bulletins. Human cases are not required to be reported, and surgeons do not habitually report cases to health officials. Investigating hospital registers and data from the Rio Grande do Sul Health Secretary MARDINI \& SOUZA ${ }^{13}$ could identifiy 701 persons, between 1981 and 1998, which made surgery to remove hydatic cyst. Official reports from the BRAZILIAN HEALTH MINISTRY ${ }^{4}$ revealed that between 1999 and 2002, 14, 8, 32, 2 cases were registered, respectively, and none from 2003 until August 2005. There are no correct explanations that can explain this lack in official data. Some points should be given attention: one is the fact that there is no payment for hydatic surgery in the Official Brazilian Health System. This way, surgeons and hospitals have to report other procedures to be reinfunded for their expenses, and for this reason hospital records are either unavailable or unreliable. Another point to be stressed while one analyses the official data is regarded to the city in which the patient lives. Only very few cases are localized in municipalities near endemic regions. Most of them are in surrounding areas from State Capital (Porto Alegre) or in cities far from endemic regions. It could be possible that many rural workers moved to cities where job opportunities are better and of course diagnosis was done there. But no case was identified in endemic areas during the analyzed period. In this way, official registers should be analyzed very carefully because they may no reflect the reality.

An interesting survey was finished in 1999 by the Health Secretary from Rio Grande do Sul State ${ }^{16}$ evaluating 7,415 inhabitants out of a total population of 140,665 which live in rural areas from the 18 municipalities that belong to the endemic zones (Some of them are presented in Fig. 1). An ELISA technique was performed in approximately $5 \%$ of the total population of rural inhabitants. Results showed different patterns in sero-prevalence and infection rate varied from 8.82 to 89.44 per 100,000 inhabitants without easy interpretation.

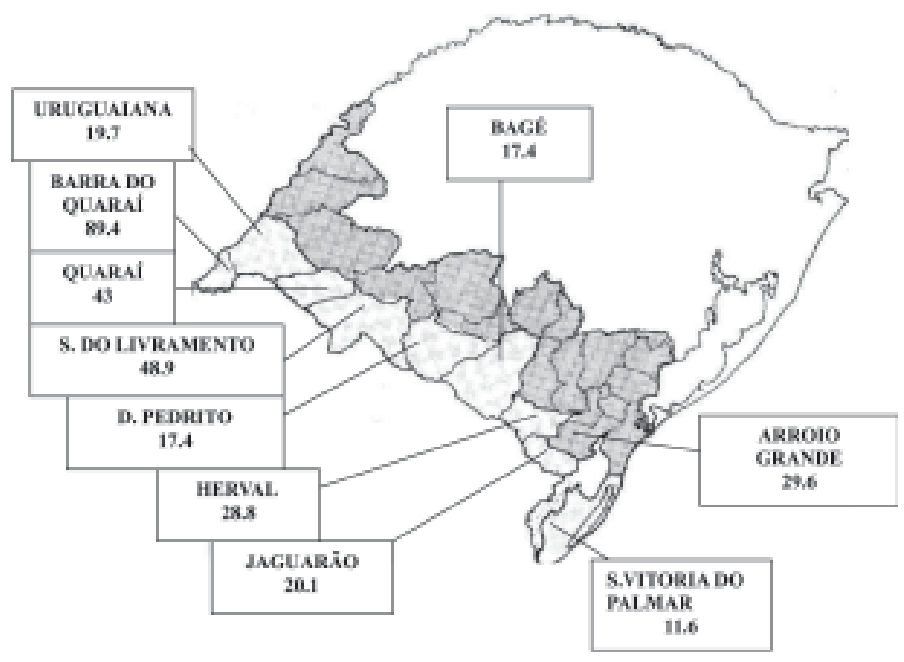

Fig. 1 - Prevalence of human cystic echinococcosis in some municipalities of endemic areas from Rio Grande do Sul State (/100,000 inhabitants-1999).
Some neighboring municipalities had very different serological response, but reasons for this wide ranging result are not evident and not analyzed in the cited work, but some explanations could help: 1substitution of cattle raising by agriculture, mainly rice crops, resulting in lower number of dogs getting infected with E. granulosus and consequently less ground contamination with Echinococcus eggs. 2sheep meet is the main animal protein source for farms personal and with improving access of electricity to rural properties there is a decrease in sheep slaughter for human consumption due to easier meat storage. 3- the indiscriminate use of benzimidazoles for nematodes treatment in sheep's could produce cyst calcification with a resulting decrease in cyst fertility. This last effect was clearly demonstrated by others ${ }^{15}$ and can explain some variations, also from farm to farm, depending directly on owner's care. 4- Decrease in sheep's number during the last 10 years. The BRAZILIAN AGRICULTURAL MINISTRY ${ }^{3}$ reported that from 1991 until 2003 total sheep's number diminished from 11,000,000 to approximately 4,000,000 which has an obvious impact in transmission conditions.

Human serology presented here may reflect a situation that happened, probably, some years ago and actually could be different due to changes in sheep and cattle prevalence in the last five years.

It is difficult to know the annual cattle slaughter in Rio Grande do Sul State, because slaughterhouses have Federal, State or Municipal Meat Inspection and there are some private abattoirs absent from official statistics. The majority of the 497 municipalities in state have meat control, but statistics on the number of analyzed animals are of difficult access. In 2004 Federal and State meat inspection registered 1,620,000 slaughter cattle (Brazilian Agricultural Ministry and State Agricultural Secretary-Personal Information), but the Leather Industry Association estimates that in the last five years there has been an annual average of $2,200,000$ industrialized leather, which probably reflects the annual number of slaughtered cattle. Echinococcus cysts found in inspected cattle may serve as a prevalence reference in the field and probably are better than sheep's data, because slaughter of the last one is very irregular and dependant on wool price and human consumption. Thus, cattle will be used here to analyze the field's situation as a better and constant indicator.

Official federal data from 1996 until 2004 showed cystic echinococcosis prevalence in Rio Grande do Sul State in slaughter cattle varying from $16 \%$ to $12 \%{ }^{3}$, respectively, with early fluctuations in prevalence. These fluctuations may be due to some seasonal influences like water shortage, meat price, demand or animals' offer, which indicate the age cattle are sent to slaughterhouses and the more the age, the easier is cyst identification of older animals.

According to BRAZILIAN AGRICULTURAL MINISTRY³ in 2004 the neighboring states (Santa Catarina, Paraná and Mato Grosso do Sul) had a cattle cyst prevalence of $0.48,0.12$ and $0.002 \%$, respectively, which shows that CE is much more important in Rio Grande do Sul.

On the other hand, it is interesting to observe that sheep's prevalence has been increasing during the last 10 years. In Fig. 2, it is clearly shown that the prevalence change from $2.46 \%$ until $17.09 \%$ of the slaughter animals. No big changes can be observed in human behavior, number of farm dogs and in slaughterhouses routine meat inspection 


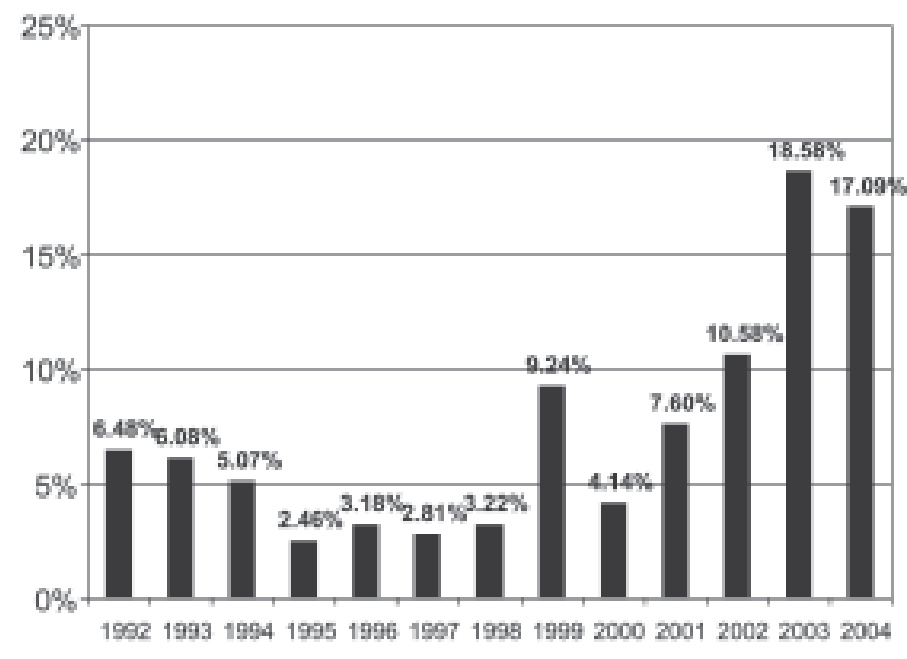

Fig. 2 - Sheep's cystic echinococcosis prevalence in Rio Grande do Sul State, Brazil in slaughterhouses with Federal Meat Inspection.

to explain the increase in infected animals, but some points should be analyzed and can influence the founded data. The first one is the apprehensiveness in rural properties of sheep robbery. This fact leads farm's personal to keep sheep herd near the house during the night. Cattle herd is maintained in the field distributed in the property without any different care. Probably this surrounding area is the most infected because dogs are normally close to humans for protection and care. Another point to consider is the internal migration from people which grew-up in non-endemic regions and bought properties in Echinococcus area. These persons are normally not aware about the parasite's harmful action and probably do not take into account the correct prophylaxis to avoid transmission.

Brazilian echinococcosis control programs are mentioned since the first agreement between Uruguayan and Brazilian governments in June $24,1941^{9}$, but very few results can be observed. Some sporadic attempts were done in the past but none continued at least for some months to produce measurable results. Recently, a pilot control program in Santana do Livramento County was conducted in which some rural and urban dogs were analyzed for the presence of E. granulosus during eight months with monthly praziquantel delivery to dogs. At projects beginning 17 out 44 (28\%) dogs in rural area had E. granulosus antigens in feces and after eight months no one was infected, but four months later nine out of 19 (47\%) had a positive ELISA test for coproantigens detection. Information about the parasite biology and importance to human health were done during each monthly visit to farms. Despite the success in eliminating Echinococcus during the program, dogs rebounded infection in numbers higher than in the beginning ${ }^{8}$. These facts show the difficulty to change some customs in the population and make them able to control the disease even with some knowledge about parasite's cycle and pathogenicity.

Actually, slaughterhouses payment for each animal is only in carcasses revenue, which means that viscera are not included. This way, the more the viscera profit the more slaughterhouses' income but it is reasonable to assume that farm owners have very little interest to spend money to control CE. It should be interesting to include these institutions in any control program, asking them to pay more for an uninfected animal which will bring a stimulus for farmers.

For the near future, some aspects can change Echinococcus situation and probably modify prevalence and epidemiological data. In many municipalities there are gradual sheep and cattle raising substitution by vineyard and irrigated rice plantations and recently by Eucalyptus due to industries' demand and better income perspectives. These facts probably could affect behavior in rural properties regarding the number of animals, extensive breeding and dog's number.

\section{RESUMO}

\section{Equinococose cística no sul do Brasil}

A equinococose cística (CE) é muito comum na região sul do estado do Rio Grande do Sul, onde a criação de bovinos e ovinos representa a maior atividade econômica. A prevalência nos hospedeiros intermediários é bem conhecida devido aos registros em frigoríficos enquanto que os casos humanos apresentam dados discutíveis e de difícil interpretação. Isto é devido a subnotificação e os poucos estudos epidemiológicos tornam difícil a avaliação da equinococose na população. Enquanto que a prevalência em bovinos estabilizou ao redor de $12 \%$ de animais abatidos na última década, em ovelhas está ocorrendo um aumento nos últimos cinco anos. Algumas tentativas estão sendo feitas para controlar esta zoonose mas não tem sido obtidos resultados práticos até agora. Provavelmente ações educativas que alterem comportamentos humanos (alimentação de cães com vísceras cruas), tratamento periódico dos cães com praziquantel e ações junto a frigoríficos poderiam resultar em incremento nas medidas de controle devido às perdas econômicas mensuráveis.

\section{REFERENCES}

1. BARTHOLOMEI-SANTOS, M.L.; HEINZELMANN, L.S.; OLIVEIRA, R.P. et al. Isolation and characterization of microsatellites from the tapeworm Echinococcus granulosus. Parasitology, 126: 599-605, 2003.

2. BASSEWITZ, E.A. - Echinococcose no Brasil. In: CONGRESSO BRASILEIRO DE MEDICINA E CIRURGIA, 6., São Paulo, 1908. Anais. v. 2, p. 583-614.

3. BRAZILIAN AGRICULTURAL MINISTRY - Rebanho bovino por estado. www.agricultura.gov.br/ (Accessed on June, 19, 2006).

4. BRAZILIAN HEALTH MINISTRY - Morbidade Hospitalar do SUS por local de internação, Rio Grande do Sul. http://w3.datasus.gov.br/datasus/datasus.php (Accessed on June, 19, 2006).

5. BRUSQUE, H.- Contribuição para o estudo do Kysto Hydatico. Pelotas, Livraria Commercial, 1918. (Tese de Doutorado - Faculdade de Medicina de Porto Alegre).

6. DE LA RUE, M.L. - Epidemiology and transmission of cystic Echinococcosis - Brazil. Arch. Int. Hidat., 32: 48-50, 1997.

7. DE LA RUE, M.L.; DINKEL, A.; MACKENSTEDT, U. \& ROMIG, T. - New data on Echinococcus spp. in southern Brazil. Rev. Inst. Med. trop. S. Paulo, 48: 102-104, 2006.

8. FARIAS, L.N.; MALGOR, R.; CASSARAVILLA, C.; BRAGANÇA, C. \& DE LARUE, M.L. - Echinococcosis in southern Brazil: efforts toward implementation of a control program in Santana do Livramento, Rio Grande do Sul. Rev. Inst. Med. trop. S. Paulo, 46: 153-156, 2004. 
DE LA RUE, M.L. - Cystic echinococcosis in southern Brazil. Rev. Inst. Med. trop. S. Paulo, 50(1): 53-56, 2008.

9. FONTANA, V.P. - Lucha contra la Hidatidosis. Arch. Int. Hidat., 6: 591-592, 1946.

10. HAAG, K.L.; ARAUJO, A.M.; GOTTSTEIN, B. et al. - Breeding systems in Echinococcus granulosus (Cestodae; Taenidae): selfing or outcrossing? Parasitology, 118: 63-71, 1999.

11. HARDEGGER, C.E. - Contribuição ao estudo do Kysto Hydático no Rio Grande do Sul. Porto Alegre, 1905. (Tese de Doutorado- Faculdade de Medicina de Porto Alegre).

12. HOFFMANN, A.N.; MALGOR, R. \& DE LA RUE, M.L. - Prevalência de Echinococcus granulosus (Batsch, 1786) em cães urbanos errantes no município de Dom Pedrito (RS), Brasil. Ciência Rural, S. Maria, 31: 843-847, 2001.

13. MARDINI, L.B.F. \& SOUZA, M.A.T. - Programa de Controle da Hidatidose humana no estado do Rio Grande do Sul. Bol. Hidat., 1998-1999: 39-43, 1999.

14. ROSENZVIT, M.C.; ZHANG, L.H.; KAMENETZKY, L. et al. - Genetic variation and epidemiology of Echinococcus granulosus in Argentina. Parasitology, 118: 523530, 1999.
15. SANTOS, H.T. - Estudo da relação entre o uso do albendazole no tratamento da verminose bovina e o decréscimo da prevalência da hidatidose em ovinos e do Echinococcus granulosus em cães no município de Uruguaiana, Rio Grande do Sul, Brasil. Santa Maria, 1995. (Dissertação de Mestrado - Universidade Federal de Santa Maria).

16. SOUZA, M.A.T.; MARDINI, L.B.L.F., FERNANDES, C. \& TIECHER, F. - Diagnóstico sorológico de hidatidose humana na população rural de 18 municípios do Rio Grande do Sul, Brasil. In: BRAZILIAN PARASITOLOGY CONGRESS, 16., Poços de Caldas, 1999. Anais. p. 35.

17. THOMPSON, R.C.A. \& McMANUS, D.P. - Towards a taxonomic revision of the genus Echinococcus. Trends Parasit., 18: 452-457, 2002.

Received: 2 July 2007

Accepted: 11 September 2007 